\title{
OPTIMIZATION THE PARAMETER PROCESS OF SOLID-STATE FERMENTATION TO PRODUCE THE FUNGAL A-AMYLASE ON AGRO-INDUSTRIAL BY-PRODUCTS
}

\author{
Rania, M. El-Feky ${ }^{1}$, Abdel Fattah, A.A. ${ }^{1}$, Gibriel, A.Y. ${ }^{1}$ and Farag, A.A. ${ }^{2}$ \\ [41] \\ 1. Food Science Dept., Fac. of Agric., Ain Shams Univ., P.O. Box 68 Hadyek \\ Shoubra11241, Cairo, Egypt \\ 2. Central Laboratory for Agric. Climate, Agric. Research Center, Dokki, Giza, Egypt. \\ *Corresponding author: abedo1978@agr.asu.edu.eg
}

Received 16 December, 2018,

Accepted 25 December, 2018

\begin{abstract}
The present work is concerned with optimization the process parameter of the production of fungal $\alpha$-amylase enzyme by Aspergillus niger ATCC 102 and Aspergillus oryzae NRRL 6270 using solid-state fermentation (SSF) process on two agro-industrial by-products. Different cultural parameter and conditions such as moisture content of prepared agro-industrial by-product (30 to $70 \%$ ), fermentation period (12 to $120 \mathrm{~h}$.) and incubation temperature $\left(25-35^{\circ} \mathrm{C}\right)$ were optimized to obtain the maximum yield of $\alpha$-amylase activity. The study is concerned to produce fungal $\alpha$ amylase on agro-industrial by-products such as inner layers of sugarcane bagasse (Saccharum officinarum) (SCB) and corn gluten meal (Zea mays) after addition of germ cake and corn steep liquor (CGM) were used as solid substrates. The optimum conditions for SSF as follows temperature at $30^{\circ} \mathrm{C}$ and two moisture content level (60-30\%) for SCB by Aspergillus niger and CGM after addition of germ cake and corn steep liquor by two fungal strains, respectively and incubation period of 72, 48, 24 hours for SCB by Aspergills niger, CGM by two fungal strains, respectively and SCB by Aspergillus oryzae, producing a-amylase activity $3.49 \mathrm{U} / \mathrm{g}$ (solid substrate) with SCB by SSF after 24 hours by Aspergillus niger, whereas $3.78 \mathrm{U} / \mathrm{g}$ (solid substrate) by Aspergillus oryzae after 48 hours. The highest record of amylase activity was obtained on SCB by SSF $3.49 \mathrm{U} / \mathrm{g}$ (solid substrate) after 24 hours by Aspergillus niger, whereas $3.78 \mathrm{U} / \mathrm{g}$ (solid substrate) by Aspergillus oryzae
\end{abstract}

after 48 hours. Optimum $\alpha$-amylase enzyme activity was observed at $30^{\circ} \mathrm{C}$. Utilization of agroindustrial by-product provides an alternative method and value-addition in cost effectiveness of bioprocess. The obtained results demonstrated that, the potential application of the used strategy for $\alpha$ amylase enzyme production from agro-industrial by-products.

Key words: Fungal alpha amylase; Agro-industrial by-products; Solid State Fermentation (SSF); Partial Purification.

\section{INTRODUCTION}

Enzymes, a vital component of the biological system and essential to sustain life (Singh et al 2016). Enzyme being the most important products obtained for human needs have stimulated renewed interest in the exploration of industrially relevant enzymes from several natural sources including plants, animals and microorganisms (Karri et al 2014). Enzymes do not only act as a catalyst; when the body has an abundant of enzymes, it can protect itself and repair the damage more than 5,000 enzymes are known (Swaroop et al 2013). Therefore, in the last years, large-scale production of amylases enzyme were carried out using solid-state and submerged fermentation using help by microorganisms like fungi.

In addition, there are two fermentation techniques i.e submerged fermentation and solid-state fermentation. Solid-state fermentation is better for the production of fungal enzymes using different substrates, like bagasse and other agriculture 
waste and paper pulp (Subramaniyam and Vimala, 2012). Solid-state fermentation is superior to submerged fermentation because of its number of additional advantages like simplicity, cost effectively, easy availability, better productivity and lesser water output (Singh et al 2016).

Filamentous fungi are suitable microorganisms for the solid-state fermentation process because their morphology with allows them to colonize and penetrate the solid substrate (Rahardjo et al 2005). Sugar cane plant are concentrated in the area of Upper Egypt specifically in Menia, Sohag, Qena, Luxor and Aswan (Dalia and El-Haggar 2014). There are eight sugarcane production factories in Egypt. During the sugar production process, a number of by-products and residues are generated one of them is bagasse which is the fibrous material generate after chopping and milling of the sugarcane for juice extraction with percentage of $30 \%$ and during the process of sugar production, three million tons of bagasse are generated annually. Corn gluten meal (CGM) is a major by-product of corn wet milling, contains (on dry basic) $67-71 \%$ proteins and $64-78 \%$ starch so the grain used for starch production. For example, In China, the residue of corn as the major crop in the world had reached 208 million tons in (2012) which is about one-fifth of the world's corn production (Liu et al 2015).

The bakery industry uses varieties of enzymes to optimize the properties of dough and to improve the quality of baked products (Gabriela et al 2016). The alpha-amylase enzyme is commonly applicable to use in bread making to improve the textural properties of bread and to reduce the elasticity (Barrera et al 2015 and Patel et al 2012). In the production of bread, amyloglucosidase is use to produce glucose from starch to enhance the fermentation process (Diler et al 2015). Damaged starch modified the physicochemical properties of wheat flour, improving higher water absorption capacity, which affects negatively on the rheological of dough behavior and bread making quality (Barrera et al 2015). Amylases help to reduce the technological problems produced from high damaged starch levels, due to the greater effect on damaged starch to enzymatic hydrolysis (Barrera et al 2015). The use of enzymes as improvers in bread making instead of chemical ones is more suitable from healthy point of view (El-Rashidy et al 2015). The current investigation was performed to produce the fungal $\alpha$-amylase enzyme on agroindustrial by-product such as sugarcane bagasse and corn gluten meal. Also, use of produced enzymes in pan brad manufacturing.

\section{MATERIALS AND METHODS}

\section{Materials}

Wheat flour (72\% extract) was purchased from Khatab Flour Mills Company. Sugarcane bagasse was obtained in one batch from Sugar and Integrated Industries Company, hawmdaya, Giza, Egypt. Corn-gluten meal (Zea mays) was obtained from Egyptian Starch and Glucose Manufacturing Company, Mostorod, Cairo, Egypt. GRINDAMYL®A 14000 (a fungal Alpha-amylase enzyme from Aspergillus oryzae) was obtained from DANISCO Company. Soluble starch; 3,5 dinitrosalicylic acid and Coomassie Brilliant blue were purchased from (Sigma). Bovine serum albumin (Merk), Maltose monohydrate, Monobasic Sodium phosphate, Dibasic Sodium Phosphate $\left(\mathrm{Na}_{2} \mathrm{HPO}_{4} \cdot 12 \mathrm{H}_{2} \mathrm{O}\right)$, Ammonium sulphate, Glucose, Agar, peptone, Yeast extract, Malt extract, Tartaric acid, Tween 80, $\mathrm{KH}_{2} \mathrm{PO}_{4}, \mathrm{MgSO}_{4}, \mathrm{NaCL}, \mathrm{NaOH}$, Rose Bengal, lodine solution, Streptomycin, Potassium Sodium Tartarate were analytical grade .

\section{Fungal strains and culture conditions}

The fungal strains used in this study Aspergillus niger ATCC 102 and Aspergillus oryzae NRRL 6270 were obtained from the Egyptian Microbial Culture Collection (EMCC) at the Microbial Resource Center (Cairo, MIRCEN), Faculty of Agriculture, Ain Shams University, Cairo, Egypt. Fungal strains was activated on potato dextrose agar (PDA) media which contain (300g potatoes; $20 \mathrm{~g}$ glucose; $15 \mathrm{~g}$ agar and $1 \mathrm{~L}$ distilled water) and $\mathrm{pH}$ of the PDA medium was adjusted to 5.6 with $10 \%$ tartaric acid. For the inoculum preparation: $10 \mathrm{ml}$ of sterilized distilled water was added to a sporulated 7 days old PDA slant culture incubated at $25^{\circ} \mathrm{C}$. Dislodge the inoculum spores under sterilized conditions, then centrifugation $\left(9000 \mathrm{~g}\right.$ at $\left.4^{\circ} \mathrm{C}\right)$ for 15 min. Collected of supernatant; then add glycerol to the suspension. Then it was diluted for the require density of spores and used as the master suspension. The number of viable spores in the inoculum determined by the counting technique using Rose Bengal medium.

\section{Preparation of agro-industrial by-products to produce fungal $\alpha$-amylase}

Inner layers of sugarcane bagasse (SCB) was dried by sun drying, then cut into small pieces with 

$\alpha$-amylase on Agro-industrial By-products

a sharp knife and ground by mixer and sieved $(2.5 \mathrm{~mm})$ sieve. The same process was follows with corn gluten meal (CGM) was by addition of germ cake and corn steep liquor.

\section{Methods of analysis:}

Chemical composition of agro-industrial byproducts

Moisture, ash, protein, lipid contents and fiber content of agro-industrial by-products were determined according to the (A.O.A.C., 2012).

\section{Extraction and determination of concentrations of $\alpha$-amylase enzyme:}

Biomass $(10 \mathrm{~g})$ of samples at different moisture level content, incubation periods and temperatures of incubation were extracted with $50 \mathrm{ml}$ of $0.2 \mathrm{M}$ phosphate buffer $\mathrm{pH} 7$. The extract was filtered, and the filtrate was centrifugation at $9000 \mathrm{~g}$ for 15 min. at $4^{\circ} \mathrm{C}$ to remove the fungal spores and unwanted particles to a final volume of $50 \mathrm{ml}$, the clear supernatant that obtained after centrifugation was used as a source of crude enzyme (Kalaiarasi and Parvatham, 2011). The concentrations of alpha amylase enzyme in crude enzyme determined by using commercial alpha amylase as standard and calculated according the following equation:

$$
Y=0.03542+0.12447 x
$$

Where $Y$ is Optical density of $\alpha$-amylase solution at different concentration and $X$ is the concentration of $\alpha$-amylase.

\section{Determination of crude enzyme protein}

The crude enzyme protein was determined by (Bradford et al 1976) using bovine serum albumen as standard. The blue color involves the binding of Coomassie Brilliant Blue G-250 to protein. The binding of the dye to protein causes a shift in the absorption maximum of the dye from 365 to $595 \mathrm{~nm}$ and it is the increase in absorption at 595 $\mathrm{nm}$ which is monitored. This assay is very reproducible and rapid with the dye binding process virtually complete in approximately 2 min with good color stability for 1 hour.

Assay of $\alpha$-amylase by 3, 5 dinitrosalicylic acid (DNS) method

Add Starch $1.0 \mathrm{ml}$, mix by swirling and equilibrate to $20^{\circ} \mathrm{C}$ then $\alpha$-amylase solution $1.0 \mathrm{ml}$ was added. Mix by swirling and incubate exactly for 3 minutes at $20^{\circ} \mathrm{C}$. Reagent E (Color Reagent Solution), Reagent G (Enzyme Reagent) each of $1 \mathrm{ml}$ was added and replace in a boiling water bath for exactly 15 minutes then cool on ice to room temperature and record the absorbance $540 \mathrm{~nm}$ for both the test and blank using a suitable spectrophotometer (Swaroop et al 2013).

Determination of the specific activity of $\alpha$ amylase:

The specific activity of the $\alpha$-amylase protein was expressed of units/mg protein according the following equation (Lily et al 2012)

Specific activity = enzyme activity (units) / protein content (mg)

\section{Salt precipitation technique}

The broth containing amylase enzyme was centrifuged for 15 minutes at $9000 \mathrm{~g}$ in $4^{\circ} \mathrm{C}$. The supernatant was collected then filtered. Volume is measured by cylinder Ammonium Sulphate should be added very slowly with continuous stirring of the solution on a magnetic stirrer in cold conditions $\left(4^{\circ} \mathrm{C} \pm 2\right)$ and the solutions are kept for overnight incubation (Lily et al 2012).

\section{Dialysis of $\alpha$-amylase enzyme against buffer}

The mouth of Dialysis Bag is first open under water. One end of the bag is tightly tied and the sample is loaded into to, after loading the sample the other end was also sealed. The dialysis bag was then suspended in a beaker containing the same buffer and the buffer in a beaker is changed every two hours for about three times, then kept in refrigerator overnight (Swaroop et al 2013).

Application of partially purified $\alpha$-amylase in pan bread manufacturing

\section{Processing of pan bread}

Pan bread was prepared according to procedure described by (Lazaridou et al 2007) with some modifications as follows: commercial baker's yeast $(3.5 \%)$ were dissolved in warm water $\left(40^{\circ} \mathrm{C}\right)$ and then added to the dry ingredients $(2 \% \mathrm{NaCl}$, $1 \%$ sugar and $100 \%$ wheat flour $72 \%$ extract) with addition of two concentration of partially purified $\alpha$ amylase (140 and $280 \mathrm{U})$. The shortening (2\%) was added and the mixture was kneaded in a mix- 
ing bowl for 4 min at a low speed then for 2 min at high speed. The dough incubated to fermentation at $30{ }^{\circ} \mathrm{C}$ and $80-85 \%$ relative humidity for $45 \mathrm{~min}$ in a fermentation cabinet. Then, dough divided into $150 \mathrm{~g}$ pieces (as pan capacity), molded, placed in the pan and proofed under the same conditions for 1h. The dough pieces were baked at $240{ }^{\circ} \mathrm{C}$ for 20-25 min. following steaming for 10 s in an electrical oven (Mondial Formi, Model No: 4T 40/60, Italy). Baked loaves were allowed to cool at the ambient temperature $\left(25^{\circ} \mathrm{C} \pm 2\right)$ for $60 \mathrm{~min}$. before measuring its volume, weight and before being sensory evaluated then packed in polyethylene bags.

\section{Sensory evaluation of pan bread}

Sensory evaluation of produced pan bread was conducted for freshly baked bread as described by (Kulp et al 1985) using 10 panelists from the staff (male and female) from Faculty of Agriculture, Ainshams University, and the quality score of pan bread included symmetry of shape (5), crust color (10), break and sheared (10), crumb texture (15), crumb color (10), aroma (20), taste (20) and mouth feel (10).

\section{Physical measurements of pan bread}

The average of weight $(\mathrm{g})$ of pan bread determined individually within one hour after baking. The volume $\left(\mathrm{cm}^{3}\right)$ of different types of produced pan bread was determined by BVM instrument. Also, the Specific volume was calculated according to the method of A.A.C.C (2012) using the following equation:

Specific volume $=$ Volume $\left(\mathrm{cm}^{3}\right) /$ Weight $(\mathrm{g})$

\section{Determination of pan bread freshness (staling rate)}

Staling rate of the pan bread was determined after $0,24,48,72$ hours of storage at $\left(25^{\circ} \mathrm{C} \pm 2^{\circ} \mathrm{C}\right)$ the ambient temperature by alkaline water retention capacity (AWRC \%) according to A.A.C.C. (2012) method as following:

AWRC \%

$=\frac{\text { Weight of tube with sample after centrifuge }- \text { weight of empty tuber }}{} \times 100$

\section{Statistical analysis}

All samples were analyzed in replicates (two or three) and the results were expressed as means \pm standard deviation. Analysis was assessed using the Statistical Analysis System software System for Windows (SAS, 2008). The significant difference between the mean values were determined by using the analysis of variance (ANOVA) and Duncan's multiple range test was conducted at a significance level of $(P \leq 0.05)$

\section{RESULTS AND DISCUSSION}

\section{Chemical composition of studied agro- industrial by-products}

Results of the chemical composition of inner layers of sugarcane bagasse and corn gluten meal were presented in Table (1). Inner layers of sugarcane bagasse contained $2.10 \%, 5.83 \%$ and $3.36 \%$ for ash contents, ether extract and protein contents, respectively. However, for corn gluten meal the corresponding results were $9.0 \%, 9.42 \%$ and $15.09 \%$, respectively. From the same table, it could be noticed that both of inner layers and corn gluten meal contained high percentage of crude fiber which were $44.43 \%$ and $41.33 \%$, respectively. The results are also cleared that, inner layers had higher value of crude fiber than corn gluten meal. Also, the same trend was observed for protein content where inner layers and corn gluten meal contained $3.36 \%$ and $15.09 \%$, respectively. These results were confirmed with those results obtained by (Liu et al 2015) and (Hemmasi et al 2011). Due to the high content of sugarcane bagasse for fiber content, it could be used as a media for microbial processes to produce $\alpha$-amylase enzyme

Table 1. Proximate chemical composition of sugarcane bagasse and corn gluten meal

\begin{tabular}{|c|c|c|}
\hline \multirow{2}{*}{$\begin{array}{c}\text { Constituents } \\
\%\end{array}$} & \multicolumn{2}{|c|}{ Agro-industrial by-products } \\
\hline & SCB & CGM \\
\hline Moisture & $7.80^{B} \pm 0.23$ & $10.95^{A} \pm 0.19$ \\
\hline Ash content & $2.10^{B} \pm 0.12$ & $9.00^{A} \pm 0.49$ \\
\hline Ether extract & $5.83^{B} \pm 0.17$ & $9.42^{\mathrm{A}} \pm 0.41$ \\
\hline Protein & $3.36^{B} \pm 0.01$ & $15.09^{A} \pm 0.01$ \\
\hline Crude fiber & $44.43^{\mathrm{A}} \pm 0.57$ & $41.33^{B} \pm 3.4$ \\
\hline Carbon & $56.80^{A} \pm 0.01$ & $53.69{ }^{B} \pm 0.02$ \\
\hline
\end{tabular}



$\alpha$-amylase on Agro-industrial By-products

Means in the same raw followed by different letters are significantly different $(P \leq 0.05)$.

\section{Concentrations of $\alpha$-amylase enzyme}

Data presented in Table (2) illustrated the concentrations of $\alpha$-amylase from inner layers of sugarcane bagasse after inoculation with the fungal strain study Aspergillus niger ATCC 102 at different moisture level content.

Table 2. Concentrations of $\alpha$-amylase $(\mathrm{mg} / \mathrm{g})$ in crude enzyme extracted from inner layers of sugarcane bagasse inoculated with Aspergillus niger ATCC 102 at different moisture content levels

\begin{tabular}{|c|c|c|c|c|c|}
\hline \multirow{2}{*}{$\begin{array}{c}\text { Fermentation } \\
\text { period }(\mathbf{h})\end{array}$} & \multicolumn{5}{|c|}{ Moisture content (\%) } \\
\cline { 2 - 6 } & $\mathbf{3 0}$ & $\mathbf{4 0}$ & $\mathbf{5 0}$ & $\mathbf{6 0}$ & $\mathbf{7 0}$ \\
\hline $\mathbf{1 2}$ & $2.39^{\mathrm{Ba}}$ & $3.53^{\mathrm{Aa}}$ & $1.46^{\mathrm{Ca}}$ & $1.48^{\mathrm{Ca}}$ & $2.08^{\mathrm{BCa}}$ \\
$\mathbf{2 4}$ & $2.09^{\mathrm{Ba}}$ & $2.99^{\mathrm{Aab}}$ & $1.51^{\mathrm{Ca}}$ & $1.55^{\mathrm{Ca}}$ & $2.15^{\mathrm{BC}}$ \\
$\mathbf{4 8}$ & $2.80^{\mathrm{ABa}}$ & $3.36^{\mathrm{Aab}}$ & $1.74^{\mathrm{Ba}}$ & $1.70^{\mathrm{Ba}}$ & $3.13^{\mathrm{Ab}}$ \\
$\mathbf{7 2}$ & $2.96^{\mathrm{Ba}}$ & $2.29^{\mathrm{BCb}}$ & $1.46^{\mathrm{Ca}}$ & $2.26^{\mathrm{BCa}}$ & $4.98^{\mathrm{Aa}}$ \\
\hline
\end{tabular}

Means in the same column followed by different small letters are significantly different $(P \leq 0.05)$ between different fermentation periods.

Means in the same row followed by different capital letters are significantly different $(P \leq 0.05)$ between different moisture content.

The obtained data showed significant $(P \leq 0.05)$ increase in concentration of $\alpha$-amylase after inoculation with the fungal strain study Aspergillus niger ATCC 102 compared with the concentration of the enzyme without inoculation which was $1.18(\mathrm{mg} / \mathrm{g})$ whereas, after inoculation with the fungal strain Aspergillus niger ATCC 102 at different moisture level content from 30 to $70 \%$ and fermentation periods from 12 to 72 hours, the highest concentration of $\alpha$-amylase was $3.53(\mathrm{mg} / \mathrm{g})$ at $40 \%$ moisture level content after 12 hours of incubation period. While, the concentration of $\alpha$-amylase was $4.98(\mathrm{mg} / \mathrm{g})$ at $70 \%$ moisture content and after 72 hours of incubation. These results are agreement with (Bhattacharya et al 2011) which the maximum productivity of amylase was achieved after $120 \mathrm{~h}$ at $30^{\circ} \mathrm{C}$ on wheat bran substrate using Aspergillus flavus, $A$. oryzae and $A$. awamori, respectively. (Cruz et al 1967) reported that, solid-state fermentation of bagasse with $60 \%$ moisture, by Aspergillus niger and Rhizopus nigricans.

The concentrations of $\alpha$-amylase from corn gluten meal after addition of germ cake and corn steep liquor after inoculation by Aspergillus niger ATCC 102 at different moisture level content were presented in Table (3). Results indicated that, the concentration of $\alpha$-amylase without inoculation was $2.98 \mathrm{mg} / \mathrm{g}$, whereas after inoculation by Aspergillus niger $\mathrm{N} 102$ at different moisture level content from 30 to $70 \%$ and fermentation periods from 12 to 72 hours, the concentration of $\alpha$-amylase was increased and the highest concentration of $\alpha$ amylase was $9.70 \mathrm{mg} / \mathrm{g}$ at $30 \%$ after 72 hours of incubation period, while the concentration of the enzyme was $8.07 \mathrm{mg} / \mathrm{g}$ at $40 \%$ after 12 hours of incubation.

Table 3. Concentrations of $\alpha$-amylase $(\mathrm{mg} / \mathrm{g})$ in crude enzyme extracted from corn gluten meal inoculated with Aspergillus niger ATCC 102 at different moisture content levels

\begin{tabular}{|c|c|c|c|c|c|}
\hline \multirow{2}{*}{$\begin{array}{c}\text { Fermentation } \\
\text { period (h) }\end{array}$} & \multicolumn{5}{|c|}{ Moisture content (\%) } \\
\cline { 2 - 6 } & $\mathbf{3 0}$ & $\mathbf{4 0}$ & $\mathbf{5 0}$ & $\mathbf{6 0}$ & $\mathbf{7 0}$ \\
\hline $\mathbf{1 2}$ & $7.67^{\mathrm{ABb}}$ & $8.07^{\mathrm{Aa}}$ & $5.06^{\mathrm{Ba}}$ & $6.02^{\mathrm{ABa}}$ & $7.81^{\mathrm{Aab}}$ \\
$\mathbf{2 4}$ & $5.89^{\mathrm{BC}}$ & $7.54^{\mathrm{Aa}}$ & $5.37^{\mathrm{BCa}}$ & $4.15^{\mathrm{Ca}}$ & $8.80^{\mathrm{Aa}}$ \\
$\mathbf{4 8}$ & $9.47^{\mathrm{Aa}}$ & $5.88^{\mathrm{Bab}}$ & $6.11^{\mathrm{Ba}}$ & $5.52^{\mathrm{Ba}}$ & $6.54^{\mathrm{Bb}}$ \\
$\mathbf{7 2}$ & $9.70^{\mathrm{Aa}}$ & $4.54^{\mathrm{Cb}}$ & $6.56^{\mathrm{Ba}}$ & $5.85^{\mathrm{Ba}}$ & $6.24^{\mathrm{Bb}}$ \\
\hline
\end{tabular}

Means in the same column followed by different small letters are significantly different $(P \leq 0.05)$ between different fermentation periods.

Means in the same row followed by different capital letters are significantly different $(P \leq 0.05)$ between different moisture content.

Similarly, (Chimata et al 2010) reported the production of amylases by solid-state fermentation (SSF) carried out by isolate Aspergillus sp. MK07, and found that amylase production $(164 \mathrm{U} / \mathrm{g}$ ) was highest on third day of incubation period at $30^{\circ} \mathrm{C}$. The result of our study varied with the above study.

Noticeably, From Table (4) there are significant $(P \leq 0.05)$ differences between the concentrations of $\alpha$-amylase at different moisture level content for the inner layers of sugarcane bagasse by-product after inoculation by Aspergillus oryzae NRRL 6270 at different moisture content levels. After 24 hours of incubation period at $30 \%$ moisture level content the concentration of alpha amylase enzyme was $1.30 \mathrm{mg} / \mathrm{g}$ compared with the concentration of the enzyme without any inoculation was $1.18 \mathrm{mg} / \mathrm{g}$, it could be noticed that there is increasing in the concentration of the enzyme when used the fungal strain that mentioned before. 
Table 4 Concentrations of $\alpha$-amylase $(\mathrm{mg} / \mathrm{g})$ in crude enzyme extracted from inner layers of sugarcane bagasse inoculated with Aspergillus oryzae NRRL 6270 at different moisture content levels

\begin{tabular}{|c|c|c|c|c|c|}
\hline \multirow{2}{*}{$\begin{array}{c}\text { Fermentation } \\
\text { period (h) }\end{array}$} & \multicolumn{5}{|c|}{ Moisture content (\%) } \\
\cline { 2 - 6 } & $\mathbf{3 0}$ & $\mathbf{4 0}$ & $\mathbf{5 0}$ & $\mathbf{6 0}$ & $\mathbf{7 0}$ \\
\hline $\mathbf{1 2}$ & $1.13^{\mathrm{Da}}$ & $2.09^{\mathrm{Ba}}$ & $1.81^{\mathrm{BCa}}$ & $1.54^{\mathrm{CDa}}$ & $2.68^{\mathrm{Aa}}$ \\
$\mathbf{2 4}$ & $1.30^{\mathrm{Aa}}$ & $2.14^{\mathrm{Aa}}$ & $1.50^{\mathrm{Aa}}$ & $1.47^{\mathrm{Aa}}$ & $1.73^{\mathrm{Aa}}$ \\
$\mathbf{4 8}$ & $1.27^{\mathrm{Ba}}$ & $1.91^{\mathrm{ABa}}$ & $1.40^{\mathrm{Ba}}$ & $1.56^{\mathrm{Ba}}$ & $2.96^{\mathrm{Aa}}$ \\
$\mathbf{7 2}$ & $1.23^{\mathrm{Ba}}$ & $2.02^{\mathrm{Aa}}$ & $1.83^{\mathrm{Aa}}$ & $1.11^{\mathrm{Ba}}$ & $1.99^{\mathrm{Aa}}$ \\
\hline
\end{tabular}

Whereas, the concentration of the enzyme was $2.14 \mathrm{mg} / \mathrm{g}$ after 24 hours of incubation period at $40 \%$ moisture level content. Although the fungal growth happened at lower moisture level (30\%), it was associated with early sporulation and a significant reduction in the enzyme yield. This could be due to the non-availability of nutrients as lower moisture content has been known to reduce the solubility of nutrients of the substrate, lower degree of swelling and high water tension affecting microbial activity. Because of high moisture level decreased porosity of particles, developed stickiness of substrate resulting in agglomeration and reduced gas volume and gaseous diffusion resulting in low oxygen transfer (Sivaramakrishnan et al 2007).

Results in Table (5) indicated that, a significant $(P \leq 0.05)$ different in the concentrations of $\alpha$ amylase in the crude enzyme from corn gluten meal at different moisture level content. There was observed increasing in the concentration of enzyme which was $7.61 \mathrm{mg} / \mathrm{g}$ after 24 hours of incubation period at $30 \%$ moisture content compared with the initial concentration of $\alpha$-amylase in the corn gluten meal without inoculation which was $2.98 \mathrm{mg} / \mathrm{g}$ and at the same moisture level content but after 48 hours of incubation with Aspergillus oryzae the concentration of $\alpha$-amylase was 7.59 $\mathrm{mg} / \mathrm{g}$ and after 72 hours of incubation at the same moisture level content the concentration of $\alpha$ amylase was $6.42 \mathrm{mg} / \mathrm{g}$. At $40 \%$ moisture content, the highest concentration of $\alpha$-amylase was 9.22 $\mathrm{mg} / \mathrm{g}$ after 12 hours, whereas at 50\% moisture content, the highest concentration of $\alpha$-amylase was $6.56 \mathrm{mg} / \mathrm{g}$ after 12 hours of incubation period, but there was an increasing in the concentration at $60 \%$ moisture content which was $6.28 \mathrm{mg} / \mathrm{g}$ after 24 hours of incubation.
Table 5. Concentrations of $\alpha$-amylase $(\mathrm{mg} / \mathrm{g})$ in crude enzyme extracted from corn gluten meal inoculated with Aspergillus oryzae NRRL 6270 at different moisture content levels

\begin{tabular}{|c|c|c|c|c|c|}
\hline \multirow{2}{*}{$\begin{array}{c}\text { Fermentation } \\
\text { period (h) }\end{array}$} & \multicolumn{5}{|c|}{ Moisture content (\%) } \\
\cline { 2 - 6 } & $\mathbf{3 0}$ & $\mathbf{4 0}$ & $\mathbf{5 0}$ & $\mathbf{6 0}$ & $\mathbf{7 0}$ \\
\hline $\mathbf{1 2}$ & $7.44^{\mathrm{Ba}}$ & $9.22^{\mathrm{Aa}}$ & $6.56^{\mathrm{BCa}}$ & $4.28^{\mathrm{Db}}$ & $5.64^{\mathrm{Cab}}$ \\
$\mathbf{2 4}$ & $7.61^{\mathrm{Aa}}$ & $7.53^{\mathrm{Aab}}$ & $3.04^{\mathrm{Bb}}$ & $6.28^{\mathrm{Aa}}$ & $6.81^{\mathrm{Aa}}$ \\
$\mathbf{4 8}$ & $7.59^{\mathrm{Aa}}$ & $4.37^{\mathrm{Bc}}$ & $5.72^{\mathrm{ABa}}$ & $3.91^{\mathrm{Bb}}$ & $5.55^{\mathrm{ABab}}$ \\
$\mathbf{7 2}$ & $6.42^{\mathrm{Aa}}$ & $6.77^{\mathrm{Ab}}$ & $5.17^{\mathrm{Aa}}$ & $4.88^{\mathrm{Aab}}$ & $4.57^{\mathrm{Ab}}$ \\
\hline
\end{tabular}

Means in the same column followed by different small letters are significantly different $(P \leq 0.05)$ between different fermentation periods.

Means in the same row followed by different capital letters are significantly different $(P \leq 0.05)$ between different moisture content.

These results are not agreement with (Ferreira et al 2014) which reported that the amylase production was the highest on 4 day of incubation period at $35^{\circ} \mathrm{C}$ when carried out in wheat bran fermented using SSF by Rhizopus oryzae strain.

\section{Determination of fungal $\alpha$-amylase activity}

Activity of $\alpha$-amylase enzyme ( $\mathrm{U} / \mathrm{g}$ solid substrate) at different moisture content and during different incubation period of inner layers of sugarcane bagasse inoculated with the fungal strain Aspergillus niger ATCC 102 are shown in Table (6). The initial activity of the enzyme of crude enzyme from inner layers of sugarcane bagasse without inoculation was $0.52 \mathrm{U} / \mathrm{g}$, while it was reached to $3.49 \mathrm{U} / \mathrm{g}$ after 24 hours of incubation at $30 \%$ moisture content. On the other hand, activity decreased to $2.95 \mathrm{U} / \mathrm{g}$ after 24 hours of incubation at $40 \%$ moisture level content. Conversely, at $50 \%$ moisture content the increasing of activity of $\alpha$ amylase enzyme not like the increasing of the activity at $30 \%$ moisture content at the same fermentation period which was $3.03 \mathrm{U} / \mathrm{g}$.

Also, clarify that the highest activity of $\alpha$ amylase enzyme of the inner layers of sugarcane bagasse inoculated with Aspergillus niger ATCC 102 after 12 hours of incubation at $50 \%$ moisture content, which was $4.06 \mathrm{U} / \mathrm{g}$.

Moisture is essential for the ramification of the fungal hyphae into any substrate and act as the prime factor to keep the pressure at the tip of the fungal hyphae. The air pockets between the fibers of bagasse trap air that preventing oxygen tension 

$\alpha$-amylase on Agro-industrial By-products

to develop in the last stages of fermentation. These results are similarly, the maximum activity of amylase was carried out in agronomic wastes and sugarcane bagasse was the best (Bhattacharya et al 2012)

Table 6. Determination of $\alpha$-amylase activity $(\mathrm{U} / \mathrm{g})$ in crude enzyme extracted from inner layers of sugarcane bagasse inoculated with Aspergillus niger ATCC 102 at different moisture content levels.

\begin{tabular}{|c|c|c|c|c|c|}
\hline Fermentation & \multicolumn{5}{|c|}{ Moisture content (\%) } \\
\cline { 2 - 6 } period (h) & $\mathbf{3 0}$ & $\mathbf{4 0}$ & $\mathbf{5 0}$ & $\mathbf{6 0}$ & $\mathbf{7 0}$ \\
\hline $\mathbf{1 2}$ & $2.97^{\mathrm{ABab}}$ & $2.97^{\mathrm{ABa}}$ & $4.06^{\mathrm{Aa}}$ & $2.38^{\mathrm{Bb}}$ & $3.82^{\mathrm{Aa}}$ \\
$\mathbf{2 4}$ & $3.49^{\mathrm{Aa}}$ & $2.95^{\mathrm{Aa}}$ & $3.03^{\mathrm{Aa}}$ & $3.29^{\mathrm{Aab}}$ & $3.49^{\mathrm{Aa}}$ \\
$\mathbf{4 8}$ & $2.25^{\mathrm{Aab}}$ & $2.84^{\mathrm{Aa}}$ & $3.06^{\mathrm{Aa}}$ & $2.44^{\mathrm{Ab}}$ & $3.62^{\mathrm{Aa}}$ \\
$\mathbf{7 2}$ & $1.93^{\mathrm{Cb}}$ & $1.91^{\mathrm{Ca}}$ & $3.35^{\mathrm{ABa}}$ & $4.23^{\mathrm{Aa}}$ & $2.90^{\mathrm{BCb}}$ \\
\hline
\end{tabular}

Means in the same column followed by different small letters are significantly different $(P \leq 0.05)$ between different fermentation periods.

Means in the same row followed by different capital letters are significantly different $(P \leq 0.05)$ between different moisture content.

Activity of $\alpha$-amylase enzyme ( $\mathrm{U} / \mathrm{g}$ solid substrate) at different moisture content levels and during different incubation period of corn gluten meal inoculated with the fungal strain Aspergillus niger ATCC 102 are shown in Table (7). The initial activity of the enzyme of crude enzyme from corn gluten meal without inoculation was $0.31 \mathrm{U} / \mathrm{g}$, and reached to $1.53 \mathrm{U} / \mathrm{g}$ after 12 hours of incubation at $30 \%$ moisture content. Meanwhile, activity decrease to $1.04 \mathrm{U} / \mathrm{g}$ after 24 hours of incubation at $40 \%$ moisture content. While at $50 \%$ moisture content, the increasing of activity of $\alpha$-amylase not like the increasing of the activity at $30 \%$ moisture content at the same fermentation period which was $1.22 \mathrm{U} / \mathrm{g}$ after 48 hours of incubation.

Table 7. Determination of $\alpha$-amylase activity $(\mathrm{U} / \mathrm{g})$ in crude enzyme extracted from corn gluten meal inoculated with Aspergillus niger ATCC 102 at different moisture content levels.

\begin{tabular}{|c|c|c|c|c|c|}
\hline Fermentation & \multicolumn{5}{|c|}{ Moisture content (\%) } \\
\cline { 2 - 6 } period (h) & $\mathbf{3 0}$ & $\mathbf{4 0}$ & $\mathbf{5 0}$ & $\mathbf{6 0}$ & $\mathbf{7 0}$ \\
\hline $\mathbf{1 2}$ & $1.53^{\mathrm{Aa}}$ & $1.13^{\mathrm{Ba}}$ & $0.82^{\mathrm{Bb}}$ & $0.93^{\mathrm{Bc}}$ & $1.10^{\mathrm{Bab}}$ \\
$\mathbf{2 4}$ & $1.13^{\mathrm{Aa}}$ & $1.04^{\mathrm{Aa}}$ & $0.86^{\mathrm{Ab}}$ & $0.71^{\mathrm{Ad}}$ & $1.11^{\mathrm{Aab}}$ \\
$\mathbf{4 8}$ & $1.49^{\mathrm{Aa}}$ & $0.61^{\mathrm{Bb}}$ & $1.22^{\mathrm{Aa}}$ & $1.51^{\mathrm{Aa}}$ & $1.19^{\mathrm{Aa}}$ \\
$\mathbf{7 2}$ & $1.53^{\mathrm{Aa}}$ & $0.80^{\mathrm{Bab}}$ & $0.88^{\mathrm{Bb}}$ & $1.12^{\mathrm{ABb}}$ & $0.89^{\mathrm{Bb}}$ \\
\hline
\end{tabular}

Means in the same column followed by different small letters are significantly different $(P \leq 0.05)$ between different fermentation periods.

Means in the same row followed by different capital letters are significantly different $(P \leq 0.05)$ between different moisture content.
Also, the obtained results clarify that, the highest activity of $\alpha$-amylase enzyme of corn gluten meal inoculated with the fungal strain Aspergillus niger ATCC 102 after 48 hours of incubation at $60 \%$ moisture content, which was $1.51 \mathrm{U} / \mathrm{g}$ (solid substrate) that was nearly that recorded at $30 \%$ moisture content after 12 hours of incubation. These results are agreement with (Chimata et al 2010).

As seen in Table (8), the results showed an increasing $(P \leq 0.05)$ in activity at different moisture content form inner layers of sugarcane inoculated with the fungal strain Aspergillus oryzae NRRL 6270 , it could be noticed that there were an increasing in activity by increasing incubation periods at $30 \%$ moisture content. The significantly increased $(p \leq 0.05)$ in activity of inner layers of sugarcane was $1.26 \mathrm{U} / \mathrm{g}$ at the beginning of incubation period (12 h.), and reached to $4.62 \mathrm{U} / \mathrm{g}$ at the end of incubation period (72 h.) While after 72 hours of incubation at $40 \%$ moisture content, the activity was $2.13 \mathrm{U} / \mathrm{g}$ and there is not increasing in the activity significant happen like the increasing in activity at 30\% moisture level content after 12 hours of the incubation.

Table 8. Determination of $\alpha$-amylase activity $(\mathrm{U} / \mathrm{g})$ in crude enzyme extracted from inner layers of sugarcane bagasse inoculated with Aspergillus oryzae NRRL 6270 at different moisture content levels.

\begin{tabular}{|c|c|c|c|c|c|}
\hline \multirow{2}{*}{$\begin{array}{c}\text { Fermentation } \\
\text { period (h) }\end{array}$} & \multicolumn{5}{|c|}{ Moisture content (\%) } \\
\cline { 2 - 6 } & $\mathbf{3 0}$ & $\mathbf{4 0}$ & $\mathbf{5 0}$ & $\mathbf{6 0}$ & $\mathbf{7 0}$ \\
\hline $\mathbf{1 2}$ & $1.26^{\mathrm{Db}}$ & $1.17^{\mathrm{Da}}$ & $3.32^{\mathrm{Ba}}$ & $3.95^{\mathrm{Aa}}$ & $2.32^{\mathrm{Ca}}$ \\
$\mathbf{2 4}$ & $3.64^{\mathrm{ABa}}$ & $2.11^{\mathrm{Ba}}$ & $2.44^{\mathrm{ABa}}$ & $3.84^{\mathrm{Aa}}$ & $3.81^{\mathrm{Aa}}$ \\
$\mathbf{4 8}$ & $3.78^{\mathrm{Aa}}$ & $1.54^{\mathrm{Ba}}$ & $3.71^{\mathrm{Aa}}$ & $3.96^{\mathrm{Aa}}$ & $3.09^{\mathrm{Aa}}$ \\
$\mathbf{7 2}$ & $4.62^{\mathrm{Aa}}$ & $2.13^{\mathrm{Ba}}$ & $3.43^{\mathrm{ABa}}$ & $4.07^{\mathrm{ABa}}$ & $3.41^{\mathrm{ABa}}$ \\
\hline
\end{tabular}

Means in the same column followed by different small letters are significantly different $(P \leq 0.05)$ between different fermentation periods.

Means in the same row followed by different capital letters are significantly different $(P \leq 0.05)$ between different moisture content.

Widespread suitability of inner layers of sugarcane bagasse may be due to the presence of sufficient nutrients where sugarcane bagasse consists of water, fibers (bast fiber like as banana fibers), small amount of soluble solids and its ability to remain loose even in moist conditions that providing a large surface area (Sivaramakrishnan et al 2007). Our results are confirmed with (Ferreira et al 2014) who reported that highest amylase activity of $6.01 \mathrm{U} / \mathrm{ml}$ of fermented wheat bran using SSF 
by Rhizopus oryzae. Similarly, fermentation of wheat bran for the production of glucoamylase enzyme by Aspergillus oryzae reported maximum activity $4.65 \mathrm{U} / \mathrm{ml}$.

Data presented in Table (9) shows the results of increasing $(p \leq 0.05)$ in activity at different moisture content from corn gluten meal inoculated with fungal strain Aspergillus oryzae NRRL 6270 it could be noticed that there were an increasing in activity by increasing incubation periods.

Table 9. Determination of $\alpha$-amylase activity $(\mathrm{U} / \mathrm{g})$ in crude enzyme extracted from corn gluten meal inoculated with Aspergillus oryzae NRRL 6270 at different moisture content levels.

\begin{tabular}{|c|c|c|c|c|c|}
\hline \multirow{2}{*}{$\begin{array}{c}\text { Fermentation } \\
\text { period (h) }\end{array}$} & \multicolumn{5}{|c|}{ Moisture content (\%) } \\
\cline { 2 - 6 } & $\mathbf{3 0}$ & $\mathbf{4 0}$ & $\mathbf{5 0}$ & $\mathbf{6 0}$ & $\mathbf{7 0}$ \\
\hline $\mathbf{1 2}$ & $2.83^{\mathrm{Aa}}$ & $1.35^{\mathrm{Bab}}$ & $1.19^{\mathrm{Ba}}$ & $1.42^{\mathrm{Ba}}$ & $0.82^{\mathrm{Cb}}$ \\
$\mathbf{2 4}$ & $1.28^{\mathrm{Aab}}$ & $1.41^{\mathrm{Aab}}$ & $0.63^{\mathrm{Ab}}$ & $1.22^{\mathrm{Aa}}$ & $0.80^{\mathrm{Ab}}$ \\
$\mathbf{4 8}$ & $3.09^{\mathrm{Aa}}$ & $0.69^{\mathrm{Bb}}$ & $0.84^{\mathrm{Bb}}$ & $1.22^{\mathrm{Ba}}$ & $0.82^{\mathrm{Bb}}$ \\
$\mathbf{7 2}$ & $0.72^{\mathrm{Bb}}$ & $2.29^{\mathrm{Aa}}$ & $0.76^{\mathrm{Bb}}$ & $1.14^{\mathrm{Ba}}$ & $1.43^{\mathrm{Ba}}$ \\
\hline
\end{tabular}

Means in the same column followed by different small letters are significantly different $(P \leq 0.05)$ between different fermentation periods.

Means in the same row followed by different capital letters are significantly different $(P \leq 0.05)$ between different moisture content.

The significantly increased $(P \leq 0.05)$ in activity of corn gluten meal was $2.83 \mathrm{U} / \mathrm{g}$ after 12 hours of incubation period and reached to $3.09 \mathrm{U} / \mathrm{g}$ after 72 h. of incubation period. While after 72 hours of incubation at $40 \%$ moisture content, the activity was $2.29 \mathrm{U} / \mathrm{g}$ and there is not increasing in the activity significant happen like the increasing in activity at $30 \%$ moisture level content after 48 hours of the incubation.

\section{Effect of moisture content on the production of $\alpha$-amylase}

Table (10) observed that, the optimum conditions for inner layers of sugarcane bagasse used as solid substrate for SSF. After inoculation by Aspergillus niger ATCC 102 and incubation for 72 $\mathrm{h}$, the enzyme extracted using phosphate buffer $\mathrm{pH} 7$ and estimated for the protein content and the enzyme activity at different moisture content. Results indicated that, parameters for obtaining maximum enzyme activity were optimized.
Table 10. Effect of moisture content on the production of a-amylase using Aspergillus niger ATCC 102 on inner layer of sugarcane bagasse byproduct under solid-state fermentation conditions at $30^{\circ} \mathrm{C}$.

\begin{tabular}{|c|c|c|c|}
\hline $\begin{array}{c}\text { Moisture } \\
\%\end{array}$ & $\begin{array}{c}\text { Protein con- } \\
\text { centration } \\
\text { (mg/g sub- } \\
\text { strate) }\end{array}$ & $\begin{array}{c}\text { Enzyme } \\
\text { activity } \\
\text { (U/g sub- } \\
\text { strate) }\end{array}$ & $\begin{array}{c}\text { Specific activity } \\
\text { (U/mg protein) }\end{array}$ \\
\hline 30 & 95.94 & 1.93 & 0.020 \\
40 & 140.31 & 2.97 & 0.021 \\
50 & 139.32 & 3.06 & 0.026 \\
60 & 146.27 & 4.23 & 0.028 \\
70 & 119.29 & 2.90 & 0.024 \\
\hline
\end{tabular}

Temperature of $30^{\circ} \mathrm{C}$, moisture content at $60 \%$ which protein content was $146.27 \mathrm{mg} / \mathrm{g}$ and activity of a-amylase was $4.23 \mathrm{U} / \mathrm{g}$, the specific activity was recorded $0.028 \mathrm{U} / \mathrm{mg}$ for 72 hours of fermentation period. Whereas, the specific activity was recorded $0.020 \mathrm{U} / \mathrm{mg}$ protein at $30 \%$ moisture content, while at $70 \%$ moisture content the specific activity was $0.024 \mathrm{U} / \mathrm{mg}$ protein.

Similarly, (Suganthi et al 2011) found that, the specific activity was recorded as $86 \mathrm{U} / \mathrm{mg}$ for amylase produced by Aspergillus niger BAN 3E, which was the highest yield in black gram bran. Zadrazil and Brunnert (1981) found that the addition of water to the substrate, the gas-phase and gas exchange changed. As the water content increases, the gas-phase is reduced and gas exchange is increasingly impeded, substrate suspension conditions become anaerobic.

On the other hand, at low water content, the growth conditions of the fungi are also sub-optimal so as to the water tension is high and degree of substrate swelling is low. The conditions for SSF were optimal generally in the intermediate range of water content.

Effect of moisture content on production of $\alpha$ amylase from corn gluten meal after inoculation with the fungal strain Aspergillus niger ATCC 102 under solid state fermentation (SSF) are shown in Table (11).

Results indicated that, at $30 \%$ moisture content the specific activity was recorded $0.012 \mathrm{U} / \mathrm{mg}$, which was the highest one. While at $40 \%$ moisture content the specific activity was $0.004 \mathrm{U} / \mathrm{mg}$, although protein content at $30 \%$ moisture content was $124.75 \mathrm{mg} / \mathrm{g}$ and the activity of enzyme was $1.49 \mathrm{U} / \mathrm{g}$, while the protein content was 290.64 $\mathrm{mg} / \mathrm{g}$ at $40 \%$ moisture content compared with the protein content at $30 \%$ moisture and activity less 

$\alpha$-amylase on Agro-industrial By-products

than at $30 \%$ moisture level content. These results are confirmed with (Suganthi et al 2011).

Table 11. Effect of moisture level content on the production of a-amylase using Aspergillus niger ATCC 102 on corn gluten meal under solid-state fermentation conditions at $30^{\circ} \mathrm{C}$

\begin{tabular}{|c|c|c|c|}
\hline Moisture \% & $\begin{array}{c}\text { Protein } \\
\text { concentra- } \\
\text { tion (mg/g } \\
\text { substrate) }\end{array}$ & $\begin{array}{c}\text { Enzyme } \\
\text { activity } \\
\text { (U/g sub- } \\
\text { strate) }\end{array}$ & $\begin{array}{c}\text { Specific } \\
\text { activity } \\
\text { (U/mg } \\
\text { protein) }\end{array}$ \\
\hline 30 & 124.75 & 1.49 & 0.012 \\
40 & 290.64 & 1.13 & 0.004 \\
50 & 299.59 & 0.86 & 0.003 \\
60 & 288.33 & 0.93 & 0.003 \\
70 & 300.41 & 1.11 & 0.004 \\
\hline
\end{tabular}

In Table (12) effect of moisture content levels on the production of $\alpha$-amylase enzyme by Aspergillus oryzae NRRL 6270 on inner layers of sugarcane bagasse under SSF are presented. It could be noticed that at $30 \%$ moisture content, the specific activity was $0.038 \mathrm{U} / \mathrm{mg}$, and this is the highest one that recorded compared with the other moisture content that studied. Moisture is essential for the ramification of the fungal hyphae into any substrate and act as the prime factor to keep the pressure at the tip of the fungal hyphae.

Table 12. Effect of moisture level content on the production of $\alpha$-amylase using Aspergillus oryzae NRRL 6270 on inner layer of sugarcane bagasse by-product under solid-state fermentation conditions at $30^{\circ} \mathrm{C}$.

\begin{tabular}{|c|c|c|c|}
\hline $\begin{array}{c}\text { Mois- } \\
\text { ture \% }\end{array}$ & $\begin{array}{c}\text { Protein con- } \\
\text { centration } \\
\text { (mg/g sub- } \\
\text { strate) }\end{array}$ & $\begin{array}{c}\text { Enzyme } \\
\text { activity } \\
\text { (U/g sub- } \\
\text { strate) }\end{array}$ & $\begin{array}{c}\text { Specific } \\
\text { activity } \\
\text { (U/mg } \\
\text { protein) }\end{array}$ \\
\hline 30 & 93.46 & 3.64 & 0.038 \\
40 & 147.93 & 2.11 & 0.014 \\
50 & 133.38 & 3.43 & 0.025 \\
60 & 132.72 & 3.84 & 0.028 \\
70 & 138.99 & 2.32 & 0.018 \\
\hline
\end{tabular}

The air pockets between the fibers of bagasse trap air that preventing oxygen tension to develop in the last stages of fermentation. These results are similarly, the maximum activity of amylase was carried out in agronomic wastes and sugarcane bagasse was the best solid substrate (Bhattacharya et al 2012).
The results illustrated $30 \%$ moisture content as the optimum moisture level content. Similarly, the results obtained by (Chimata et al 2010) while they observed that, production of extracellular amylase by solid state fermentation (SSF) employing a laboratory isolate Aspergillus sp MK07 has been studied. Highest enzyme production was obtained with wheat bran as a substrate. It was found that amylase production $(164 \mathrm{U} / \mathrm{g})$ was highest at $70 \%$ initial moisture content as compared to $30 \%$ moisture content in our study. Utilization of various agro-based residues for solid-state fermentation by Aspergillus oryzae is an economical method of enzyme production

In Table (13) effect of moisture content on the production of a-amylase enzyme by Aspergillus oryzae NRRL 6270 on corn gluten meal after addition of germ cake and corn steep liquor under SSF are presented.

It could be noticed that, at $30 \%$ moisture content, the specific activity was $0.009 \mathrm{U} / \mathrm{mg}$, and this is the highest one that recorded compared with the other moisture content that studied. Similarly, Kahlon and Das (1987) observed that, the optimum moisture content of $40 \mathrm{ml} / 10 \mathrm{~g}$ of rice straw fermented in SSF by Plurotus ostratus.

Table 13. Effect of moisture level content on the production of a-amylase using Aspergillus oryzae NRRL 6270 on corn gluten meal under solid-state fermentation conditions at $30^{\circ} \mathrm{C}$.

\begin{tabular}{|c|c|c|c|}
\hline Moisture \% & $\begin{array}{c}\text { Protein concen- } \\
\text { tration (mg/g } \\
\text { substrate) }\end{array}$ & $\begin{array}{c}\text { Enzyme } \\
\text { activity } \\
\text { (U/g sub- } \\
\text { strate) }\end{array}$ & $\begin{array}{c}\text { Specific } \\
\text { activity } \\
\text { (U/mg } \\
\text { protein) }\end{array}$ \\
\hline 30 & 134.19 & 1.28 & 0.009 \\
40 & 293.80 & 1.35 & 0.005 \\
50 & 283.53 & 0.76 & 0.004 \\
60 & 298.27 & 1.22 & 0.004 \\
70 & 315.47 & 0.80 & 0.003 \\
\hline
\end{tabular}

\section{Effect of fermentation period on the production of $\alpha$-amylase}

The fermentation period plays an important role in substrate utilization and its protein for enzyme production. The effect of fermentation period with Aspergillus niger ATCC 102 was evaluated by checking enzyme activities after 12, 24, 48, 72, 96 and $120 \mathrm{~h}$ of incubation at $30^{\circ} \mathrm{C}$, a-amylase activities were determined after every $12 \mathrm{~h}$ of incubation to obtain the optimum incubation time for maximum 
production of extracellular enzyme, the data are summarized in Table (14).

The maximum yield of $\alpha$-amylase $(0.028 \mathrm{U} / \mathrm{mg})$ was observed after $72 \mathrm{~h}$. Similarly, the maximum productivity of amylase was achieved in $120 \mathrm{~h}$ at $30^{\circ} \mathrm{C}$ on wheat bran substrate using starch and urea as supplement for $A$. oryzae and Thermomyces lanuginosus, respectively (Kunamneni et al 2005).

Table 14. Effect of fermentation period on the production of $\alpha$-amylase from inner layers of sugarcane bagasse inoculated by Aspergillus niger ATCC 102 under solid state fermentation conditions at $30^{\circ} \mathrm{C}$.

\begin{tabular}{|c|c|c|c|}
\hline $\begin{array}{c}\text { Fermenta- } \\
\text { tion period } \\
\text { (h) }\end{array}$ & $\begin{array}{c}\text { Protein } \\
\text { concentra- } \\
\text { tion (mg/g } \\
\text { substrate) }\end{array}$ & $\begin{array}{c}\text { Enzyme } \\
\text { activity } \\
\text { (U/g sub- } \\
\text { strate) }\end{array}$ & $\begin{array}{c}\text { Specific } \\
\text { activity } \\
\text { (U/mg pro- } \\
\text { tein) }\end{array}$ \\
\hline 12 & 148.26 & 2.38 & 0.016 \\
24 & 150.92 & 3.29 & 0.021 \\
48 & 138.00 & 2.44 & 0.017 \\
72 & 146.27 & 4.23 & 0.028 \\
96 & 135.02 & 0.09 & 0.0006 \\
120 & 167.63 & 0.57 & 0.0034 \\
\hline
\end{tabular}

The results presented in Table (15) depicted the enzyme activity was determined every $12 \mathrm{~h}$. of incubation to determine the optimum incubation period for maximum production of extracellular $\alpha$ amylase and protein content to obtain the specific activity.

Table 15. Effect of fermentation period on the production of $\alpha$-amylase from corn gluten meal inoculated by Aspergillus niger ATCC 102 under solid state fermentation conditions $30^{\circ} \mathrm{C}$.

\begin{tabular}{|c|c|c|c|}
\hline $\begin{array}{c}\text { Fermen- } \\
\text { tation } \\
\text { period (h) }\end{array}$ & $\begin{array}{c}\text { Protein con- } \\
\text { centration } \\
\text { (mg/g sub- } \\
\text { strate) }\end{array}$ & $\begin{array}{c}\text { Enzyme } \\
\text { activity } \\
\text { (U/g sub- } \\
\text { strate) }\end{array}$ & $\begin{array}{c}\text { Specific } \\
\text { activity } \\
\text { (U/mg pro- } \\
\text { tein) }\end{array}$ \\
\hline 12 & 108.52 & 1.53 & 0.014 \\
24 & 107.36 & 1.13 & 0.011 \\
48 & 124.75 & 1.49 & 0.016 \\
72 & 131.04 & 1.53 & 0.013 \\
96 & 241.81 & 0.80 & 0.003 \\
120 & 209.69 & 0.29 & 0.001 \\
\hline
\end{tabular}

Increase in the incubation period more than $120 \mathrm{~h}$ resulted a decrease in the production of $\alpha$ amylase. The highest specific activity was ob- served after $48 \mathrm{~h}$ of fermentation period which was enzyme activity $1.49 \mathrm{U} / \mathrm{g}$ and the protein content $124.75 \mathrm{mg} / \mathrm{g}$. These results were agreement with (Bhattacharya et al 2011).

The results presented in Tables (16) and (17) illustrated that, the effect of fermentation period on the production of $\alpha$-amylase in two different byproducts which were inner layers of sugarcane bagasse and corn gluten meal inoculation with the fungal strain A.oryzae NRRL 6270 . The results showed that, maximum production of $\alpha$-amylase (specific activity was $0.038 \mathrm{U} / \mathrm{mg}$ after $24 \mathrm{~h}$ and $0.024 \mathrm{U} / \mathrm{mg}$ after $48 \mathrm{~h}$ ) in inner layers of sugarcane bagasse and corn gluten meal, respectively. Similarly, the maximum productivity of amylase was achieved in $120 \mathrm{~h}$ at $30^{\circ} \mathrm{C}$ on wheat bran substrate using starch and urea as supplement for $A$. oryzae and Thermomyces lanuginosus, respectively (Kunamneni et al 2005).

Table 16. Effect of fermentation period on the production of $\alpha$-amylase from inner layers of sugarcane bagasse inoculated by Aspergillus oryzae NRRL 6270 under solid state fermentation conditions $30^{\circ} \mathrm{C}$.

\begin{tabular}{|c|c|c|c|}
\hline $\begin{array}{c}\text { Fermenta- } \\
\text { tion period } \\
\text { (h) }\end{array}$ & $\begin{array}{c}\text { Protein con- } \\
\text { centration } \\
\text { (mg/g sub- } \\
\text { strate) }\end{array}$ & $\begin{array}{c}\text { Enzyme } \\
\text { activity } \\
\text { (U/g sub- } \\
\text { strate) }\end{array}$ & $\begin{array}{c}\text { Specific } \\
\text { activity } \\
\text { (U/mg pro- } \\
\text { tein) }\end{array}$ \\
\hline 12 & 96.77 & 1.26 & 0.013 \\
24 & 93.46 & 3.64 & 0.038 \\
48 & 115.48 & 3.78 & 0.032 \\
72 & 158.52 & 4.62 & 0.029 \\
96 & 127.57 & 4.09 & 0.032 \\
120 & 106.40 & 3.91 & 0.036 \\
\hline
\end{tabular}

Table 17. Effect of fermentation period on the production of $\alpha$-amylase from corn gluten meal inoculated by $A$. oryzae NRRL 6270 under solid-state fermentation conditions $30^{\circ} \mathrm{C}$.

\begin{tabular}{|c|c|c|c|}
\hline $\begin{array}{c}\text { Fermenta- } \\
\text { tion period } \\
\text { (h) }\end{array}$ & $\begin{array}{c}\text { Protein con- } \\
\text { centration } \\
\text { (mg/g sub- } \\
\text { strate) }\end{array}$ & $\begin{array}{c}\text { Enzyme } \\
\text { activity } \\
\text { (U/g sub- } \\
\text { strate) }\end{array}$ & $\begin{array}{c}\text { Specific } \\
\text { activity } \\
\text { (U/mg pro- } \\
\text { tein) }\end{array}$ \\
\hline 12 & 134.19 & 2.83 & 0.021 \\
24 & 134.19 & 1.28 & 0.009 \\
48 & 131.04 & 3.09 & 0.024 \\
72 & 289.98 & 0.72 & 0.002 \\
96 & 274.94 & 1.36 & 0.009 \\
120 & 225.75 & 1.07 & 0.007 \\
\hline
\end{tabular}



$\alpha$-amylase on Agro-industrial By-products

\section{Effect of incubation temperature on the produc- tion of $\alpha$-amylase}

Effect of incubation temperature on the production of $\alpha$-amylase in two different by-products, which were inner layers of sugarcane bagasse and corn gluten meal inoculated with the fungal strain Aspergillus niger ATCC 102 under solid state fermentation conditions are summarized in Tables (18) and (19).

Aspergillus niger ATCC 102 when inoculated at different temperatures 25,30 and $35^{\circ} \mathrm{C}$ showed maximum yield of $\alpha$-amylase (specific activity was $0.0289 \mathrm{U} / \mathrm{mg}$ and $0.012 \mathrm{U} / \mathrm{mg}$ for inner layers of sugarcane bagasse and corn gluten meal respectively) at $30{ }^{\circ} \mathrm{C}$. Bhattacharya et al (2011) reported that, decrease in enzyme yield at high temperatures when temperature is not than optimum provided, this is due to reduction in metabolic activity and damage action of the cell membrane of the fungus. It was found that, maximum production of a-amylase was carried out at $30{ }^{\circ} \mathrm{C}$ by A.flavus and penicillium fellutanum.

Table 18. Effect of incubation temperature on the production of $\alpha$-amylase from inner layers of sugarcane bagasse inoculated by Aspergillus niger ATCC 102 under solid state fermentation conditions $30^{\circ} \mathrm{C}$.

\begin{tabular}{|c|c|c|c|}
\hline $\begin{array}{c}\text { Incubation } \\
\begin{array}{c}\text { Temperature } \\
\left({ }^{\circ} \mathbf{C}\right)\end{array}\end{array}$ & $\begin{array}{c}\text { Protein con- } \\
\text { centration } \\
\text { (mg/g sub- } \\
\text { strate) }\end{array}$ & $\begin{array}{c}\text { Enzyme } \\
\text { activity } \\
\text { (U/g sub- } \\
\text { strate) }\end{array}$ & $\begin{array}{c}\text { Specific } \\
\text { activity } \\
\text { (U/mg } \\
\text { protein) }\end{array}$ \\
\hline 25 & 132.87 & 0.011 & 0.00008 \\
30 & 146.27 & 4.23 & 0.0289 \\
35 & 145.62 & 0.13 & 0.00089 \\
\hline
\end{tabular}

Table 19. Effect of incubation temperature on the production of $\alpha$-amylase from corn gluten meal inoculated by Aspergillus niger ATCC 102 under solid-state fermentation conditions $30^{\circ} \mathrm{C}$.

\begin{tabular}{|c|c|c|c|}
\hline $\begin{array}{c}\text { Incubation } \\
\text { Tempera- } \\
\text { ture }\left({ }^{\circ} \mathbf{C}\right)\end{array}$ & $\begin{array}{c}\text { Protein } \\
\text { concentra- } \\
\text { tion }(\mathbf{m g} / \mathbf{g} \\
\text { substrate) }\end{array}$ & $\begin{array}{c}\text { Enzyme } \\
\text { activity } \\
(\mathbf{U} / \mathbf{g} \\
\text { sub- } \\
\text { strate) }\end{array}$ & $\begin{array}{c}\text { Specific } \\
\text { activity } \\
(\mathbf{U} / \mathbf{m g} \text { pro- } \\
\text { tein) }\end{array}$ \\
\hline 25 & 261.51 & 0.50 & 0.0019 \\
30 & 124.75 & 1.50 & 0.012 \\
35 & 253.91 & 0.57 & 0.0022 \\
\hline
\end{tabular}

The results presented in Tables (20) and (21) illustrated that, the effect of incubation temperature on the production of $\alpha$-amylase in two different byproducts which were inner layers of sugarcane bagasse and corn gluten meal inoculation with the fungal strain $A$. oryzae NRRL 6270 . The results showed that, Aspergillus oryzae when inoculated at different temperatures $25^{\circ} \mathrm{C}, 30^{\circ} \mathrm{C}$ and $35^{\circ} \mathrm{C}$ showed maximum yield of $\alpha$-amylase (specific activity was $0.038 \mathrm{U} / \mathrm{mg}$ and $0.025 \mathrm{U} / \mathrm{mg}$ for inner layers of sugarcane bagasse and corn gluten meal respectively) at $30^{\circ} \mathrm{C}$. Further increase in temperature led to acceleration of the denaturation induced by higher physiological temperature. It is widely known that a high temperatures enzymatic activity can by destroyed because enzymes are protinaceous molecules. In a similar finding by (Kupski et al 2012) that optimum temperature was at $30{ }^{\circ} \mathrm{C}$ for SSF of rice bran using Rhizopus oryzae.

Table 20. Effect of incubation temperature on the production of $\alpha$-amylase from inner layers of sugarcane bagasse inoculated by Aspergillus oryzae NRRI 6270 under solid-state fermentation conditions $30^{\circ} \mathrm{C}$.

\begin{tabular}{|c|c|c|c|}
\hline $\begin{array}{c}\text { Incubation } \\
\text { Tempera- } \\
\text { ture }\left({ }^{\circ} \mathbf{C}\right)\end{array}$ & $\begin{array}{c}\text { Protein } \\
\text { concentra- } \\
\text { tion (mg/g } \\
\text { substrate) }\end{array}$ & $\begin{array}{c}\text { Enzyme } \\
\text { activity } \\
\text { (U/g sub- } \\
\text { strate) }\end{array}$ & $\begin{array}{c}\text { Specific } \\
\text { activity } \\
\text { (U/mg pro- } \\
\text { tein) }\end{array}$ \\
\hline 25 & 115.82 & 3.82 & 0.037 \\
30 & 93.46 & 3.64 & 0.038 \\
35 & 119.31 & 3.60 & 0.030 \\
\hline
\end{tabular}

Table 21. Effect of incubation temperature on the production of $\alpha$-amylase from corn gluten meal inoculated by Aspergillus oryzae NRRI 6270 under solid-state fermentation conditions $30^{\circ} \mathrm{C}$.

\begin{tabular}{|c|c|c|c|}
\hline $\begin{array}{c}\text { Incubation } \\
\text { Tempera- } \\
\text { ture }\left({ }^{\circ} \mathbf{C}\right)\end{array}$ & $\begin{array}{c}\text { Protein } \\
\text { concentra- } \\
\text { tion }(\mathbf{m g} / \mathbf{g} \\
\text { substrate) }\end{array}$ & $\begin{array}{c}\text { Enzyme } \\
\text { activity } \\
\mathbf{( U / g} \\
\text { sub- } \\
\text { strate) }\end{array}$ & $\begin{array}{c}\text { Specific } \\
\text { activity } \\
(\mathbf{U} / \mathbf{m g} \text { pro- } \\
\text { tein) }\end{array}$ \\
\hline 25 & 255.74 & 1.27 & 0.009 \\
30 & 131.04 & 3.09 & 0.025 \\
35 & 245.61 & 1.03 & 0.004 \\
\hline
\end{tabular}

\section{CONCLUSION}

It was demonstrated that Aspergillus niger ATCC 102 and Aspergillus oryzae NRRL 6270 has 
potential for production of fungal enzyme $\alpha$ amylase. Various moisture level content, fermentation period and temperature of incubation were studied to optimize the conditions to carry out solid-state fermentation of inner layers of sugarcane bagasse and corn gluten meal after addition of germ cake and corn steep liquor. Under all the optimized cultural conditions which were temperature $30^{\circ} \mathrm{C}, 30 \%$ moisture content and inoculum $1 \times 10^{6} \mathrm{spores} / \mathrm{ml}$. Utilization of various agroindustrial residues for solid state fermentation by fungal strains that studied is an economical method of enzyme production.

\section{REFERENCES}

A.A.C.C., 2012. International Methods Approved of the American Association of Cereal Chemists, $11^{\text {th }}$ Ed., American Association of Cereal Chemists, INC. St., Paul, Minnesota, USA.

A.O.A.C., 2012. Official Methods of Analysis of the Association of Official Analytical Chemistry. International, $19^{\text {th }}$ Ed., Gaithersburg, Maryland, USA.

Barrera, G.N., Leo'n, A.E. and Ribotta, P.D., 2015. Use of enzymes to minimize the rheological dough problems caused by high levels of damaged starch in starch-gluten systems. J. Sci. Food Agric., 96, 2539-2546.

Bhattacharya, S., Bhardwaj, S., Das, A. and Anand, S., 2011. Utilization of sugarcane bagasse for solid state fermentation and characterization of $\alpha$ - amylase from Aspergillus flavus isolated from Muthupettai Mangrove, Tamil Nadu, India. Australian Journal of Basic and Applied Sci., 5(12), 1012-1022.

Bhattacharya, S., Das, A. and Rajan, S.S. 2012. Solid state fermentation and characterization of a-amylase from a Rhizospheric isolate of Aspergillus flavus associated with Mangifera indica. Annals of Biological Res., 3 (8), 40824090.

Bradford, M.M., 1976. A rapid and sensitive method for the quantitation of microgram quantities of protein utilizing the principle of protein-dye binding. Analytical Biochemistry, 72, 248254.

Chimata, M.K., Sasidhar, P. and Challa, S., 2010. Production of extracellular amylase from agricultural residues by a newly isolated Aspergillus species in solid state fermentation. Afr. J. Biotechnol., 9 (32), 5162-5169.
Cruz, R.A., Malasia, R.E., Cruz, T.J. and Pusag, C.C., 1967. Biological treatment of bagasse enhances its value as a solid conditioner or feed. Sugar News, 43, 15-19.

Dalia, A.N. and El-Haggar, S., 2014. A proposal to environmentally balanced sugarcane industry in Egypt. International J. of Agricultural Policy and Res.; 2(9), 321-328.

Diler, G., Chevallier, S., Pöhlmann, I., Guyon, C., Guilloux, M. and Le-Bail, A., 2015. Assessment of amyloglucosidase activity during production and storage of laminated pie dough. Impact on raw dough properties and sweetness after baking. J. Cereal Sci., 61, 63-70.

El-Rashidy, L.A., Bahlol, H.E.M. and El-Desoky, A.A., 2015. Improving quality of Pan bread by using glucose oxidase and lipase enzymes. Middle East J. Applied Sci., 5 (4), 1035-1043.

Ferreira, O.E., Montijo, N.A., da Silva Martins, E. and Mutton, M.J.R., 2014. Production of alpha amylase by solid state fermentation by Rhizopus oryzae. Afr. J. Biotech., 14, 622-628.

Gabriela, N.B., Tadini, C.C., Leo'n, A.E. and Ribotta, P.D., 2016. Use of alpha-amylase and amyloglucosidase combinations to minimize the bread quality problems caused by high levels of damaged starch. J. Food Sci. Technol.; 53(10), 3675-3684.

Hemmasi, A.H., Samariha, A., Tabei, A., Nemati, M. and Khakifirooz, A., 2011. Study of morphological and chemical composition of fibers from Iranian sugarcane bagasse. J. Agric. and Environ. Sci.; 11(4), 478-481.

Kahlon, S.S. and Das, S.K., 1987. Biological conversion of paddy straw into feed. Biological Waste, 22, 1-11.

Kalaiarasi, K. and Parvatham, R., 2011. Parametric optimization of extracellular $\alpha$-amylase recovery from the fermented bran of Aspergillus awamori MTCC 9997. Afri. J. Microbiol. Res., 5 (17), 2474-2478.

Karri, S., Talla, S.G., Renuka and Sunny, D., 2014. Screening and production optimization of alpha amylase from Aspergillus strains by using solid-state fermentation. Int. J. Curr. Microbiol. App. Sci., 4, 623-631.

Kulp, K., Chung, H., Martinez-Anaya, M.A. and Doerry, W., 1985. Fermentation of water ferments and bread quality. Cereal Chemistry, 32, 55-59.

Kunamneni, A., Permaul, K. and Singh, S. 2005. Amylase production in soild state fermentation by the thermophilic fungus Thermomyces lanu- 

$\alpha$-amylase on Agro-industrial By-products

ginosus. J. Biosec. and Bioengineering; 100(2), 168- 171.

Kupski, L., Pagnussatt, F.A., Buffon, J.G. and Furlong, E.B., 2012. Endoglucanase and total cellulose from newly isolated Rhizopus oryzae and Trichoderma reesei: production, characterization, and thermal stability. Appl. Biochem. Biotechnol.; 172 (1), 458- 468.

Lazaridou, A., Duta, D., Papageorgiou, M., Belc, N. and Biliaderis, C. G., 2007. Effects of hydrocolloids on dough rheology and bread quality parameters in gluten-free formulations. Journal of Food Engineering, 79, 1033-1047.

Lily, M.K., Bahuguna, A., Bhatt, K.K. and Dangwal, K., 2012. Production, partial purification and characterization of $\alpha$-amylase from high molecular weight polycyclic aromatic hydrocarbons (HMW-PAHs) degrading Bacillus subtilis BMT4i (MTCC 9447). Turk. J. Biochem., 37(4), 463-470.

Liu, X., Zheng, X., Song, Z., Liu, X., Kopparapu, N.K., Wang, X. and Zheng, Y., 2015. Preparation of enzymatic prepared corn gluten meal hydrolysate and in vivo evaluation of its antioxidant activity. J. Functional Foods, 18, 11471157.

Patel, M.J. Ng, J.H.Y., Hawkins, W.E., Pitts, K.F. and Chakrabarti-Bell, S., 2012. Effects of fungal a-amylase on chemically leavened wheat flour doughs. J. Cereal Sci., 56, 644-651

Rahardjo, Y.S.P., Weber, F.J., Haemers, S., Tramper, J., Rinzema, A., 2005. Aerial mycelia of Aspergillus oryzae accelerate a-amylase production in a model solid-state fermentation system. Enzyme Microb. Technol., 36, 900902.
SAS Program, 2008. SAS System for Windows, Statistical Analysis System. Version 9.2. Cary, USA: SAS Institute Inc.

Singh, R., Mittal, A., Kumar, M. and Praveen K.M., 2016. Amylases: A note on current applications. Int. Res. J. Biological Sci., 5(11), $27-$ 32.

Sivaramakrishnan, S., Ganghadharan, D., Nampoothiri, K.M., Soccol, C.R. and Pandey, A., 2007. Alpha Amylase Production by Aspergillus oryzae employing Solid-State Fermentation. J. Sci. and Industrial Res., 66, 621-627.

Subramaniyam, R. and Vimala, R., 2012. Solid state and submerged fermentation for the production of bioactive substances: A comparative study. Int. J. Sci. Nature, 3 (3), 480-486.

Suganthi, R., Benazir, J.F., Santhi, R., Ramesh Kumar, V., Anjana Hari, Nitya Meenakshi, Nidhiya, K.A., Kavitha, G. and Lakshmi, R. 2011. Amylase production by Aspergillus niger under solid state fermentation using agroindustrial wastes. Int. J. Engineering Sci. Technol., 3 (2), 1756- 1763.

Swaroop, G., Vinod, K.G. and Ashwini K., 2013. A comparative study on extraction, purification and characterization of amylase enzyme from Aspergillus niger and Aspergillus awamori. Int. J. of Biol. Res., 1 (2), 23-28.

Zadrazil, F. and Brunnert, H., 1981. Investigation of physical parameters important for the solid state fermentation of straw by white rot fungi. Eur. J. Appl. Microbiol. Biotechnol., 11, 183188. 



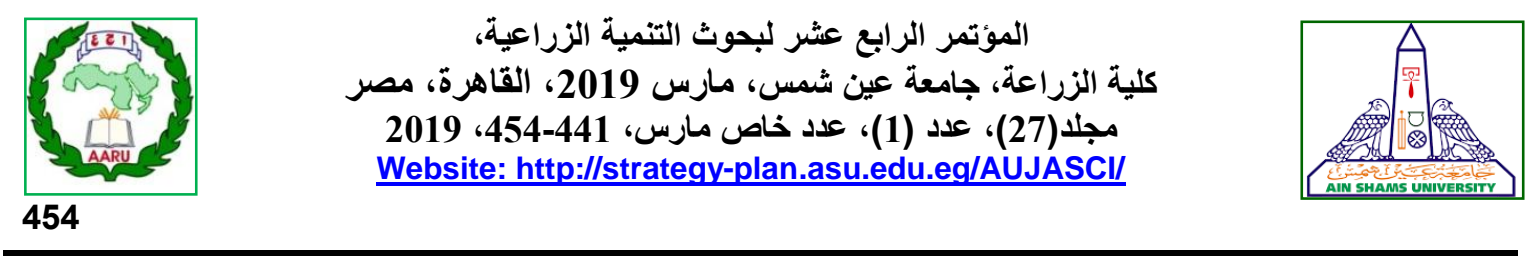

إختيار الظروف المثلي باستخدام تقتية التخمر بالمواد الصلبة لإنتاج إنزيم الألفا أميليز الفطري

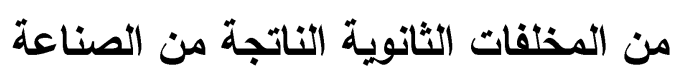

[41]

$$
\begin{aligned}
& \text { رانيا منعاز الفقي 1- عبد الفتاح عبد الكريم عبد الفتاح'- أحمد يوسف جبريل1 - أحمد عوني فرج2 }
\end{aligned}
$$

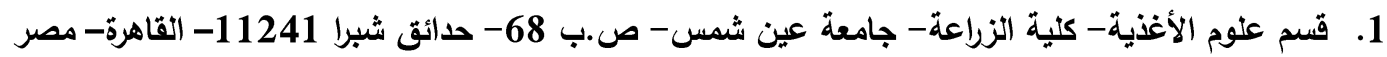

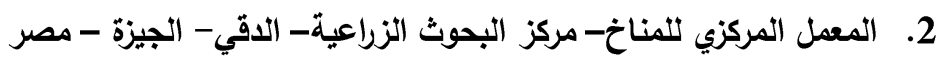

*Corresponding author: abedo1978@agr.asu.edu.eg

Received 16 December, 2018, $\quad$ Accepted 25 December, 2018

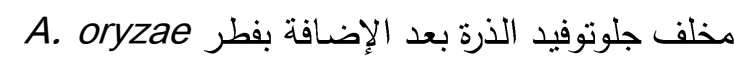

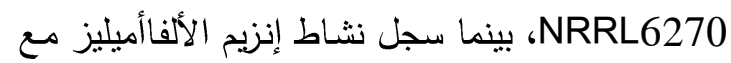

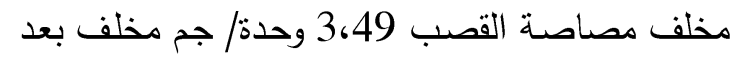
24 ساعة من التخمر بسـلالة Aiger

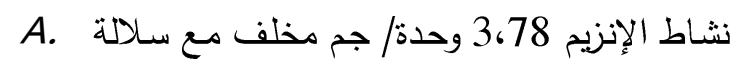

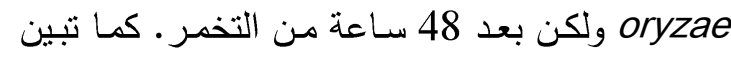

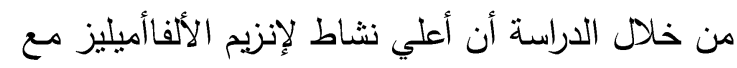

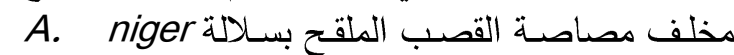

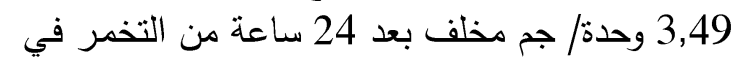

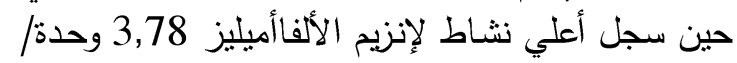

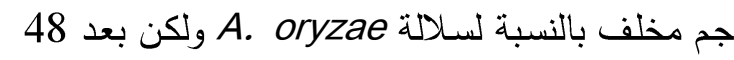
ساعة من التخمر ـ كما لوحظ أن نشاط الإنزيم الأمثل

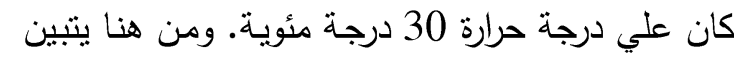

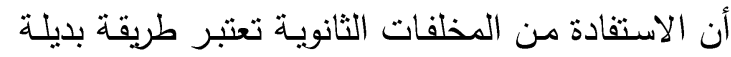

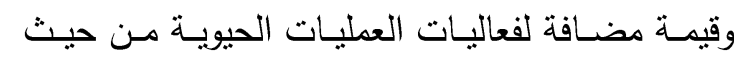
التكلفة حيث أظهرت النتائج التي تم الحصول التهات عليها

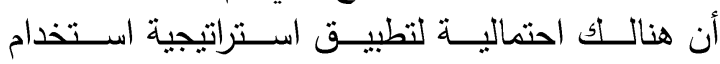
المخلفات الناتجة من الصناعة لإنتاج إنزيم الألفاأميليز الفطري.

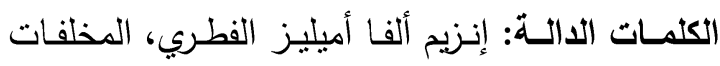

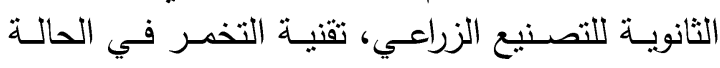
الصلبة، التنقية الجزئية

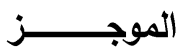

يهتم هذا البحث باختيار الظروف المثلي لإنتاج إنزيم

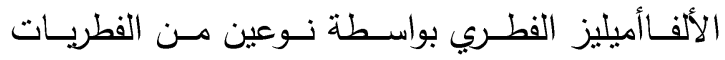
Aspergillus niger ATCC 102, Aspergillus oryzae NRRL 6270

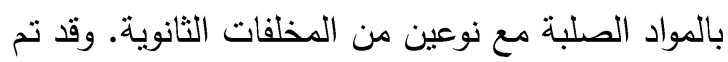

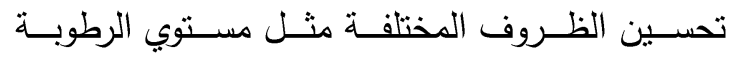

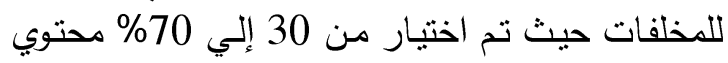

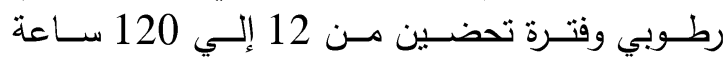

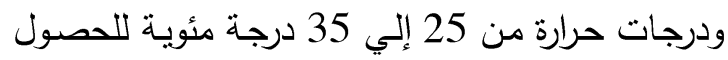
علي أقصي نشاط للإنزيم. كما تهتم هذه الدراسـة بإنتاج

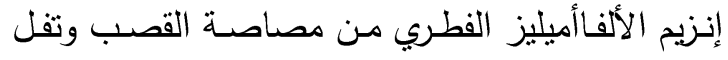

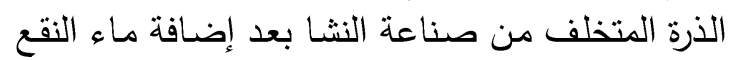

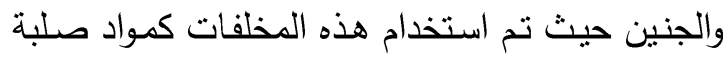

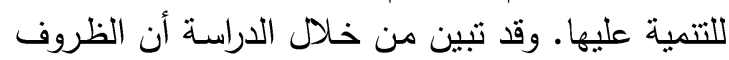

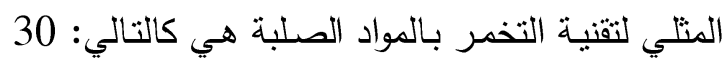

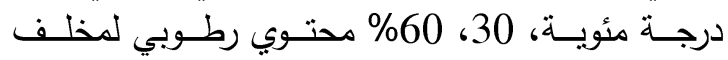

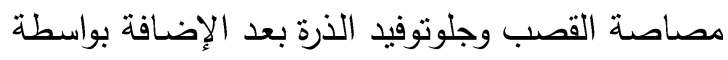
Aspergillus niger ATCC نوعين من الفطريات 102, Aspergillus oryzae NRRL 6270 التوالي وفترة تحضـين 72، 48، 24 سـاعة لمخلف مصاصة القصب مع سلالة 102 A. niger ATCC 